\title{
The Effect of Strategy Instruction on the Frequency of Reading Strategy Use by Iranian EFL Learners
}

\author{
Nasser Ghafoori ${ }^{1, *}$, Hedayat Eslami ${ }^{2, *} \&$ Leyli Bagheri ${ }^{3}$ \\ ${ }^{1}$ Department of English, Tabriz Branch, Islamic Azad University, Tabriz, Iran \\ ${ }^{2}$ Department of English, Miandoab Branch, Islamic Azad University, Miandoab, Iran \\ ${ }^{3}$ Department of English, Malekan Branch, Islamic Azad University, Malekan, Iran \\ *Correspondence: Islamic Azad University, Miandoab Branch, Miandoab, Iran. Tel: 98-091-4381-0969. E-mail: \\ eslami_hedayat@yahoo.com
}

Received: March 27, $2016 \quad$ Accepted: April 9, 2016 Online Published: April 27, 2016

doi:10.5430/ijelt.v3n2p37 URL: http://dx.doi.org/10.5430/ijelt.v3n2p37

\begin{abstract}
The purpose of this study was to scrutinize the effect of strategy instruction on the frequency of reading strategy use as reported by Iranian EFL learners. To this end, two EFL intact classes were selected from Islamic Azad university of Malekan. Then, each of them was randomly assigned to act as control group (CG) and experimental group (Exp.). Both groups were required to respond to the Reading Strategy Inventory for Language Learning (SILL) questionnaire before and after treatment. The treatment included teaching a number of most commonly used reading strategies for a period of three months. After the treatment, both groups were again required to respond to the same questionnaire. The results indicated that there were significant differences between the CG and the Exp. groups in reporting the frequency of reading strategies in the posttest. EFL teachers can benefit from the findings of this study in the field of communication, task-based L2 classes, and reading strategies to enhance the EFL students' reading comprehension.
\end{abstract}

Keywords: strategy instruction; reading strategy; learning strategies; strategy frequency

\section{Introduction}

The role of strategy in reading comprehension has been a topic of discussion in the L2 reading literature. Recent conception of reading comprehension depicts efficient readers as strategic or constructively responsive readers who meticulously employ cognitive resources when reading (Pressley \& Afflerbach, 1995). According to Horiba (2013), "flexible, strategic reading proficiency requires that individuals possess the ability to adjust cognitive processes and strategies in order to fit a reading goal in a given situation" (p. 98). In this regard, Anderson (2002) maintained that strategic reading refers to the readers' abilities to utilize a wide variety of reading strategies in order to achieve a purpose for reading. He further asserted that strategic reading is one of the four most important components of effective reading, the three others being the reader, the text, and fluent reading.

Reading, therefore, requires that readers be strategic and make use of their knowledge of language and the information about the topic under discussion to decipher meaning (Kong, 2006). With regard to reading strategies, the major focus of research in second language reading has been on scrutinizing the general reading strategies of readers and the degree to which strategy training can enhance overall reading comprehension (Singhal, 2001).The reading process is no longer limited to the analysis of vocabularies and structures of the sentences, rather it entails making use of different reading strategies (Rokhsari, 2012).

When readers face problems in comprehending the text, they attempt to utilize specific strategies to surmount the barriers in reading (Tercanlioglu, 2004). Therefore, instruction can be effective in providing students with a repertoire of strategies that boost comprehension monitoring and foster comprehension (Dreyer \& Nel, 2003). The students, thus, need instruction or training in reading which is systematically orchestrated in order to be motivated strategic strategy users (Alexander, 1996, as cited in Dreyer \& Nel, 2003). 
A number of studies (e.g., Anderson, 2002; Oxford, 1990; O'Malley \& Chamot, 1990; Mokhtari \& Sheorey, 2002; Pressley \& Afflerbach, 1995) have pointed out that one of the key characteristics of the skilled readers has to do with their ability to effectively employ reading strategies. Skilled readers employ a wide range of strategies with high frequency whereas unskilled readers' use of strategy use is very limited in its range and frequency (Poole, 2009). Reading strategies indicate how readers perceive a task and what steps they take in order to comprehend and make sense of the reading materials (Singhal, 2001).

It follows that teaching readers how to utilize specific reading strategies is a prime consideration in the L2 reading classroom (Anderson, 1991; Anderson, 2002; Oxford, 1990). Consequently, language teachers are obliged to develop effective instructional needs for teaching reading comprehension and reading strategy use if they intend to satisfy the reading needs of the students (Singhal, 2001). This study, therefore, aims at providing the EFL students with explicit and direct strategy training in the classroom in an attempt to make them aware of the variety of strategies they can employ to enhance their reading ability. As a result, the following research question was proposed regarding strategy training in order to achieve the purpose of the study:

RQ: Does reading strategy instruction have any significant effect on Iranian EFL students' frequency of strategy use at the intermediate level?

\section{Review of Related Literature}

\subsection{Learning Strategies}

One of most significant factors contributing to students' success in deciding how-and how well to learn a second or foreign language has to do with L2 learning strategies. These strategies have been defined as specific behaviors or thought processes that students employ to enhance their own L2 learning (Oxford, 2003). In other words, learning strategies are "the conscious thoughts and actions that learners take in order to achieve a learning goal" (Chamot, 2004, p. 14). Oxford (1990) pragmatically described learning strategies as "specific actions taken by the learner to make learning easier, faster, more enjoyable, more self-directed, more effective, and more transferable to new situation" ( P.2).

\subsection{Reading Strategy Use and Instruction}

In the last two decades, most of the studies in reading literature on L1, L2 and Foreign Language (FL) has focused on the strategies that readers utilize to process written input (Zhang \& Wu, 2009). Reading strategies show the readers' conception of a task, their process of making-meaning from the text, and their interaction with the text during comprehension failure (Macaro \& Erler, 2008; Singhal, 2001). Garner (1987) defined reading strategies operationally as "generally deliberate, planned activities undertaken by active learners, many times to remedy perceived cognitive failure" (P.5). He argued that reading strategies facilitate reading comprehension and can be teachable. The reading strategies can facilitate the internalization, storage, retrieval or use of the new language (Oxford, 1992).

Readers utilize a number of reading strategies in the reading process including focusing on vocabulary, using text structure, summarizing, visualizing, invoking prior knowledge, predicting, evaluating (Kong, 2006), note-taking, summarizing, inferencing, using prior knowledge, predicting, analyzing, and using context clues (Oxford, 1990).

Another important issue in teaching learner strategies to L2 learners is the language of instruction that is far from resolved. In this regard, Chamot (2004) argued that early stages of instruction in language learning strategies can be carried out in the learners' native language provided all the students in the class speak the same L1 and the teacher is familiar with and knows that language. The problem, however, is that students will be deprived of exposure to and practice in the target language. In order to overcome this situation, language teachers have to use a target language name for a particular strategy, elucidate the use of this strategy in simple language, and repeatedly model the strategy (Chamot, Barnhardt, El-Dinary, \& Robbins, 1999).

\subsection{Strategy Use}

It is argued that students will be able to utilize cognitive tools (i.e., strategies) to assist them in making the text more comprehensible provided that they are cognizant of their reading abilities, the difficulty of the reading task, and their goal in reading (Poole, 2009). In the language classroom, therefore, students need to learn how to use effective strategies for the particular types of tasks they need to achieve in their L2 learning. Moreover, it is of utmost importance that language teachers strive to help their students select the most appropriate and effective strategy for a given task (Chamot, 2004). 


\subsection{Empirical Studies on Reading Strategies}

Empirical studies abound in the area of L2 strategic reading instruction that have probed the efficacy of strategy instruction techniques. The findings of these studies indicate that students receiving strategy training outperformed those who did not receive such instruction (e.g., Phakiti, 2006; Oxford, 2003).

Salataci and Akyel (2002) examined the reading strategies of Turkish EFL students in Turkish and English and the possible effects of reading instruction on reading in Turkish and English. They found that strategy instruction had a positive effect on both Turkish and English reading strategies and reading comprehension in English.

Anani sarab and Seif Reihani (2010) investigated the relationship between test takers' cognitive and metacognitive strategy use and their second language reading test performance. They found that test takers used both contributory and non-contributory strategies to get the correct answer. The test takers' pattern of strategy use revealed a tendency towards the more frequent use of 'returning to passage' as a contributory strategy and 'guessing' as non-contributory strategy. The results of their study also revealed that the contributory and non-contributory strategies functioned differently when their use was compared across easy and difficult test passage.

Karbalaei (2010) conducted a study in which he compared the metacognitive reading strategies used by EFL and ESL readers in reading academic texts in English. The results of his study revealed that the subjects in both groups reported a similar pattern of strategy awareness while reading academic texts although the two student groups had been schooled in significantly different socio-cultural environments. The study also indicated that Indian students reported more awareness and use of global support and total metacognitive reading strategies, while Iranian students reported no significant difference in using problem-solving reading strategies.

Fazilatfar (2011) conducted a study of reading strategies using task-based strategy assessment. In order to examine the use of reading strategies, he used a strategy-frequency questionnaire in which the participants themselves reported their strategy use after completing some language tasks. The results revealed that neither task difficulty or proficiency level alone, nor their interaction had a statistically significant effect on the reported frequency of reading strategy use.

Nahatame (2014) investigated the effect of strategy instruction on the predictive inference generation during second language (L2) reading. In his study, he provided the Japanese students with several short narative passages designed to elicit predictive inferences under instruction either to comprehend the passage or to anticipate the outcome of the events described. He found that inferences were generated only when instruction fostered prediction. In addition, the facilitation effect of instruction was prominent among higher L2 proficiency readers.

\section{Methodology}

\subsection{Participants}

The participants of this study included three intact classes consisting of 54 junior EFL university students majoring in Teaching English as a Foreign Language (TEFL) in Islamic Azad university of Malekan branch. The participants included female and male EFL students at the intermediate level with the age range of 20-29. Their language background were Azeri, Farsi, and Kurdish. Of these students, 18 ones took part in the pilot study and the rest $(n=36)$ participated in the actual study.

\subsection{Instruments and Materials}

The first instrument was Preliminary English Test (PET) version (2006), as a language proficiency test, which was used to attest the homogeneity of the participants of the study. The test comprised speaking, listening, reading, and writing parts.

The second instrument was a reading strategy use questionnaire adopted from Oxford's (1986-1990) Strategy Inventory for Language Learning (SILL). The questionnaire consisted of 50 items of different strategies and the participants were required to respond to the questionnaire. The 50 strategy items on this questionnaire were classified into 6 major categories of memory, cognitive, compensation, metacognitive, affective and social. The students' reports of strategy use were evaluated based on a 5-point Likert-type scale which ranged from 1 to 5 .

The material used in this study were selected from the book Interaction 2 reading ( $4^{\text {th }}$ edition) by Kirn and Hartmann (2002) which EFL learners studied as part of a four-credit course for reading 4 in the fourth semester of the academic year. 


\subsection{Procedure}

The study took place in two phases: The pilot study and the main study.

\subsubsection{The Pilot Study}

As a first step, the reading section of the language proficiency test consisting of 35 reading items and the reading strategy questionnaire were administered to a number of 18 students with characteristics similar to the target groups in order to ascertain the internal consistency of the reading test and determine the reliability of the questionnaire using Cronbach's alpha formulae.

In the next step, the two participant groups of the study each comprising 18 students were given the language proficiency test (PET) to ensure that they were homogenous in terms of language ability. The two groups' scores were collected and recorded for analysis.

\subsubsection{The Main Study}

In the first step of the main study, the two homogeneous groups were required to respond to the SILL before strategy training. Based on the statements covered in the questionnaire, the participants were asked to choose one of the five choices, based on Likert Scale, which they themselves prefer in completing reading tasks.

In the second step (i.e., reading strategy instruction), the researchers had to actually teach the students some of the important reading strategies selected from the list of strategies used by Ozek and Civelek (2006), Salataci and Akyel (2002), and Singhal (2001) in their strategy instruction. These strategies included pre-reading, while-reading, and post-reading strategies such as skimming, scanning, skipping some unknown words, reading title, using background knowledge, summarizing, note-taking (Ozek \& Civelek, 2006); using dictionary, prediction, inferences, reference, summarizing (Salataci \& Akyel, 2002); Previewing text, employing context clues, word division, guessing, main idea (Singhal, 2001).

The instructional procedure was based on the stages similar to those used by Cotterall (1990, as cited in Salataci \& Akyel, 2002). In the first session, the teacher explained the objectives of the course and told the students what they would study and what their roles were during the learning process. The CG, was taught the reading lessons traditionally without talking about the reading strategies. The second group, Exp., received strategy training.

Finally, after teaching reading strategies for a period of three months, the reading strategy questionnaire was again administered as the post-test to record the two groups' responses.

\section{Results and Discussion}

\subsection{The Results of Pilot Study}

The results of KR-21 formulae used to estimate the internal consistency of the reading section of the language proficiency test indicated that this section enjoyed a satisfactory index of reliability (i.e., $r=.86$ ) as shown in Table 1.

Table 1. The Internal Consistency of the Reading Section of PET

\begin{tabular}{ccccccc}
\hline test & N of case & $\begin{array}{c}\text { N of } \\
\text { question }\end{array}$ & Mean & Std. Deviation & Variance & KR-21 \\
\hline Proficiency test & 18 & 35 & 17.11 & 6.45 & 41.63 & 0.86 \\
\hline
\end{tabular}

The reliability of the questionnaire was also estimated using Cronbach's alpha formula which turned out to be $r=.75$ as shown in Table 2.

Table 2. The Reliability of the Questionnaire (SILL)

\begin{tabular}{lccc}
\hline test & N of cases & N of Items & Cronbach's alpha \\
\hline Questionnaire & 18 & 50 & 0.75 \\
\hline
\end{tabular}

In order to ensure the homogeneity of the two participant groups in terms of language ability, an independent samples t-test was run the result of which, as illustrated in Table 3, revealed that $p$ value was larger than .05 ( $p>05$ ) implying that the difference among the participant groups was not significant and that they were homogeneous in terms of language ability. 
Table 3. The Results of an Independent Samples T-Test for the Homogeneity of the Two Groups

\begin{tabular}{lllllll}
\hline & $\mathrm{N}$ & Mean & \multirow{2}{*}{$\begin{array}{l}\text { Std. } \\
\text { Deviation }\end{array}$} & $\mathrm{t}$ & $\mathrm{df}$ & P value \\
\cline { 5 - 7 } & & & Dest & \multicolumn{3}{c}{ T test } \\
Exp. & 18 & 32.13 & 13.64 & .355 & 58 & 0.72 \\
\hline
\end{tabular}

\subsection{The Results of Main Study}

In the pre-test, the responses of the two participant groups (i.e., CG and Exp.) to the 50 strategy items on the SILL were collected and analyzed. The descriptive statistics for the mean score frequency of the two groups' responses on the six strategy categories of the SILL are presented in Table 4.

Table 4. The Descriptive Statistics for the Frequencies Reported by the Two Groups on the Questionnaire (Pre-Test)

\begin{tabular}{lcccc}
\hline & \multicolumn{2}{c}{ CG $(\mathrm{n}=18)$} & \multicolumn{2}{c}{ Exp. $(\mathrm{n}=18)$} \\
\hline Strategy & Mean & Std. D & Mean & Std. D \\
\hline 1. memory & 16.44 & 4.19 & 16.89 & 3.74 \\
2.cognitive & 28.33 & 6.09 & 26.06 & 4.22 \\
3.compensation & 9.33 & 3.90 & 9.00 & 3.88 \\
4.metacognitive & 19.22 & 6.26 & 16.94 & 5.25 \\
5.affetive & 10.39 & 3.71 & 10.22 & 4.36 \\
6.social & 9.76 & 4.67 & 10.06 & 2.53 \\
\hline
\end{tabular}

After the treatment, the two participant groups were again required to respond to the SILL in order to examine the effect of strategy instruction on their reported frequencies of reading strategy use. The descriptive statistics for the reported mean score frequency based on their responses to the questionnaire are provided in Table 5.

Table 5. The Descriptive Statistics for the Frequencies Reported by the Two Groups on the Questionnaire (Post-Test)

\begin{tabular}{llclc}
\hline & & CG $(\mathrm{n}=18)$ & & Exp.1 $(\mathrm{n}=18)$ \\
\hline Strategy & Mean & Std. D & Mean & Std. D \\
\hline 1. memory & 17.44 & 4.89 & 26.89 & 3.72 \\
2.cognitive & 29.03 & 6.79 & 38.28 & 4.65 \\
3.compensation & 8.93 & 3.50 & 15.67 & 4.63 \\
4.metacognitive & 18.62 & 5.66 & 23.44 & 4.82 \\
5.affetive & 10.99 & 4.31 & 14.22 & 4.91 \\
6.social & 10.08 & 4.97 & 14.28 & 3.59 \\
\hline
\end{tabular}

\subsection{Testing the Null Hypothesis}

The research hypothesis stated that strategy instruction does not have any significant effect on Iranian EFL students' frequency of strategy use at the intermediate level.

Before testing the research hypothesis using ANCOVA, three main assumptions of normality of the distribution of scores $(p>.05)$, the slope of the regression ( $>0.05)$, and equality of error variances $(p>.05)$ had to be met. The results of these three analyses for the data are presented in Tables 6 through 8.

Table 6. One-Sample Kolmogorov-Smirnov Test for Normal Distribution of the Scores of Six Strategy Categories in Exp. and CG

\begin{tabular}{lcccccc}
\hline & \multicolumn{3}{c}{ Pre Test } & \multicolumn{3}{c}{ Post Test } \\
\cline { 2 - 6 } strategy category & $\mathrm{N}$ & $\begin{array}{c}\text { Kolmogorov-S } \\
\text { mirnov Z }\end{array}$ & $\mathrm{P}$ value & $\mathrm{N}$ & $\begin{array}{c}\text { Kolmogorov- } \\
\text { Smirnov Z }\end{array}$ & P value \\
\hline Memory & 36 & 0.84 & 0.47 & 36 & 0.66 & 0.77 \\
Cognitive & 36 & 0.86 & 0.45 & 36 & 0.58 & 0.89 \\
Compensation & 36 & 0.79 & 0.57 & 36 & 0.64 & 0.81 \\
Metacognitive & 36 & 0.53 & 0.94 & 36 & 0.40 & 1.00 \\
Affective & 36 & 0.78 & 0.57 & 36 & 0.53 & 0.94 \\
Social & 36 & 0.72 & 0.68 & 36 & 0.66 & 0.77 \\
\hline
\end{tabular}


Table 7. Covariance to Examine the Slope of the Regression for the Scores of Six Strategy Categories in Exp. and CG

\begin{tabular}{clccccc}
\hline & & $\begin{array}{c}\text { Type III Sum } \\
\text { of Squares }\end{array}$ & df & $\begin{array}{c}\text { Mean } \\
\text { Square }\end{array}$ & F & P value \\
\hline \multirow{5}{*}{ Group $\times$} & Memory & 47.91 & 2 & 23.96 & 2.77 & 0.08 \\
pre test & Cognitive & 20.09 & 2 & 10.05 & 0.61 & 0.55 \\
& Compensation & 21.68 & 2 & 10.84 & 0.78 & 0.47 \\
& Metacognitive & 13.92 & 2 & 6.96 & 0.29 & 0.75 \\
& Affective & 32.01 & 2 & 16.01 & 1.44 & 0.26 \\
& Social & 20.31 & 2 & 10.15 & 0.84 & 0.44 \\
\hline
\end{tabular}

Table 8. Levene's Test of Equality of Error Variances for the Scores of Six Strategy Categories in Exp. and CG

\begin{tabular}{lcccc}
\hline & F & df1 & df2 & P value \\
\hline Memory & 2.02 & 1 & 34 & .08 \\
Cognitive & 2.52 & 1 & 34 & .11 \\
Compensation & 2.45 & 1 & 34 & .12 \\
Metacognitive & 1.29 & 1 & 34 & .26 \\
Affective & 2.68 & 1 & 34 & .09 \\
Social & 2.44 & 1 & 34 & .06 \\
\hline
\end{tabular}

Having confirmed the three afore-mentioned assumptions, the statistical technique of ANCOVA was used to test the research hypothesis. First, the descriptive statistics for the scores of the two groups of CG and Exp. on the six strategy categories in the pretest and posttest were computed, regardless of the effect of the intervening variable (pretest scores), in order to compare the mean scores of the groups in the pretest and posttest. The results of this analysis are shown in Table 9.

Table 9. Descriptive Statistics for the Scores of Six Strategy Categories for Exp. and CG in Pretest and Post Test

\begin{tabular}{|c|c|c|c|c|c|c|c|c|c|}
\hline \multirow{3}{*}{$\begin{array}{l}\text { strategy } \\
\text { category }\end{array}$} & \multirow[b]{3}{*}{ group } & \multicolumn{4}{|c|}{ Pre test } & \multicolumn{4}{|c|}{ Post test } \\
\hline & & \multirow[b]{2}{*}{ Mean } & \multirow{2}{*}{$\begin{array}{c}\text { Std. } \\
\text { Deviati } \\
\text { on }\end{array}$} & \multicolumn{2}{|c|}{$\begin{array}{l}95 \% \text { Confidence } \\
\text { Interval for Mean }\end{array}$} & \multirow[b]{2}{*}{ Mean } & \multirow{2}{*}{$\begin{array}{c}\text { Std. } \\
\text { Deviati } \\
\text { on }\end{array}$} & \multicolumn{2}{|c|}{$\begin{array}{l}95 \% \text { Confidence } \\
\text { Interval for Mean }\end{array}$} \\
\hline & & & & Lower & Upper & & & Lower & Upper \\
\hline \multirow[t]{2}{*}{ Memory } & Exp & 16.89 & 3.74 & 15.03 & 18.75 & 26.89 & 3.72 & 25.04 & 28.74 \\
\hline & $\mathrm{CG}$ & 16.44 & 4.19 & 14.36 & 18.53 & 17.14 & 4.89 & 15.06 & 19.23 \\
\hline \multirow{2}{*}{ Cognitive } & Exp & 26.06 & 4.22 & 23.96 & 28.15 & 38.28 & 4.65 & 35.97 & 40.59 \\
\hline & CG & 28.33 & 6.09 & 25.31 & 31.36 & 29.03 & 6.79 & 26.01 & 32.06 \\
\hline \multirow{4}{*}{$\begin{array}{l}\text { Compensati } \\
\text { on } \\
\text { Metacogniti } \\
\text { ve }\end{array}$} & Exp & 9.00 & 3.88 & 7.07 & 10.93 & 15.67 & 4.63 & 13.37 & 17.97 \\
\hline & CG & 9.33 & 3.90 & 7.40 & 11.27 & 8.93 & 3.50 & 7.00 & 10.87 \\
\hline & Exp & 16.94 & 5.25 & 14.33 & 19.56 & 23.44 & 4.82 & 21.05 & 25.84 \\
\hline & CG & 19.22 & 6.26 & 16.11 & 22.34 & 18.62 & 5.66 & 15.51 & 21.74 \\
\hline \multirow{2}{*}{ Affective } & Exp & 10.22 & 4.36 & 8.05 & 12.39 & 14.22 & 4.91 & 11.78 & 16.66 \\
\hline & CG & 10.39 & 3.71 & 8.54 & 12.23 & 10.99 & 4.31 & 9.14 & 12.83 \\
\hline \multirow{2}{*}{ Social } & Exp & 10.06 & 2.53 & 8.80 & 11.31 & 14.28 & 3.59 & 12.49 & 16.07 \\
\hline & CG & 9.78 & 4.67 & 7.45 & 12.10 & 10.08 & 4.97 & 7.75 & 12.04 \\
\hline
\end{tabular}

Then, in order to find out whether there is any significant difference between the CG and Exp. among the six strategy categories, the multivariate test was employed. The results of this analysis, as shown in Table 10, revealed that there was a significant difference between the two groups in at least one of the six dependent variables of the study $(\mathrm{p}<0.05)$.

Table 10. Multivariate Test for the Scores of Six Strategy Categories in Exp.1 and CG

\begin{tabular}{lccccc}
\hline & Value & F & Hypothesis df & Error df & P value \\
\hline Wilks' Lambda & 0.13 & 23.69 & 6 & 21 & 0.00 \\
Hotelling's Trace & 6.77 & 23.69 & 6 & 21 & 0.00 \\
\hline
\end{tabular}


In the next step, ANCOVA was used to compare the mean scores of the six strategy categories in the two groups (i.e., CG \& Exp.). The results of this analysis, shown in Table 11, indicated that there was a significant difference among the six strategy categories (i.e., memory, cognitive, compensation, metacognitive, affective, social) because in all the six categories the $\mathrm{p}$ value was smaller than $.05(\mathrm{p}<0.05)$. Therefore, the null hypothesis stating that strategy training does not affect the frequency of EFL learners' strategy use is safely rejected $(\mathrm{p}<.05)$ because there were significant differences between the frequencies of strategies reported by the two groups (i.e., CG and Exp) before and after treatment.

Table 11. ANCOVA for Comparing the Scores of Six Strategy Categories in Exp. and CG

\begin{tabular}{|c|c|c|c|c|c|c|c|c|}
\hline & Source & $\begin{array}{l}\text { Type III } \\
\text { Sum of } \\
\text { Squares }\end{array}$ & Df & $\begin{array}{l}\text { Mean } \\
\text { Square }\end{array}$ & $\mathrm{F}$ & $\mathrm{P}$ value & $\begin{array}{l}\text { Partial Eta } \\
\text { Squared }\end{array}$ & $\begin{array}{c}\text { Observed } \\
\text { Power }\end{array}$ \\
\hline \multirow{6}{*}{ 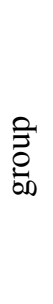 } & Memory & 894.01 & 1 & 894.01 & 91.75 & 0.00 & 0.77 & 1.00 \\
\hline & Cognitive & 1151.26 & 1 & 1151.26 & 71.97 & 0.00 & 0.72 & 1.00 \\
\hline & Compensation & 409.85 & 1 & 409.85 & 29.86 & 0.00 & 0.52 & 1.00 \\
\hline & Metacognitive & 235.85 & 1 & 235.85 & 10.47 & 0.00 & 0.27 & 0.88 \\
\hline & Affective & 126.65 & 1 & 126.65 & 11.02 & 0.00 & 0.28 & 0.89 \\
\hline & Social & 133.98 & 1 & 133.98 & 11.18 & 0.00 & 0.29 & 0.90 \\
\hline
\end{tabular}

In the last step, the effect of intervening variable (i.e., pretest scores) was controlled and the final estimates of the mean scores of the two groups (i.e., CG and Exp.) on six strategy categories, shown in Table 12, indicate the differences in the mean scores of the two groups.

Table 12. Final Estimates of the Mean Scores of Six Strategy Categories after Controlling the Effect of Pretest Scores in CG and Exp

\begin{tabular}{|c|c|c|c|c|c|}
\hline \multirow{2}{*}{$\begin{array}{l}\text { strategy } \\
\text { category }\end{array}$} & \multirow[b]{2}{*}{ group } & \multirow[b]{2}{*}{ Mean } & \multirow[b]{2}{*}{ Std. Error } & \multicolumn{2}{|c|}{ 95\% Confidence Interval } \\
\hline & & & & Lower Bound & Upper Bound \\
\hline \multirow{2}{*}{ Memory } & Exp & 26.94 & 0.76 & 25.39 & 28.49 \\
\hline & $\mathrm{CG}$ & 16.39 & 0.76 & 14.84 & 17.94 \\
\hline \multirow{2}{*}{ Cognitive } & Exp & 39.29 & 0.97 & 37.30 & 41.28 \\
\hline & CG & 27.32 & 0.97 & 25.33 & 29.31 \\
\hline \multirow{2}{*}{ Compensation } & Exp & 16.07 & 0.90 & 14.23 & 17.91 \\
\hline & CG & 8.93 & 0.90 & 7.09 & 10.77 \\
\hline \multirow{2}{*}{ Metacognitive } & Exp & 24.04 & 1.15 & 21.68 & 26.40 \\
\hline & CG & 18.62 & 1.15 & 16.27 & 20.98 \\
\hline \multirow{2}{*}{ Affective } & Exp & 14.29 & 0.82 & 12.61 & 15.98 \\
\hline & CG & 10.32 & 0.82 & 8.63 & 12.01 \\
\hline \multirow{2}{*}{ Social } & Exp & 14.07 & 0.84 & 12.35 & 15.79 \\
\hline & $\mathrm{CG}$ & 9.99 & 0.84 & 8.27 & 11.71 \\
\hline
\end{tabular}

\subsection{Discussion}

The results of this study revealed that all the participants in the two CG and Exp. groups were affected by the treatment (i.e., strategy instruction) and their reported frequencies of reading strategies in the posttest were significantly better than pretest.

The results of statistical analysis of ANCOVA revealed that there were significant differences on the frequencies reported by the participants in the CG and Exp. on all the six categories of SILL (i.e., memory, cognitive compensation, metacognitive, affective, social) in the posttest. This means that strategy instruction in the classroom was conducive in enhancing the use of reading strategies by EFL learners. In this sense, the results of this study are consistent with Salataci and Akyel (2002), Onovughe and Hannah (2011), and Khezrlou (2012) who found that strategy training provided by the teacher contributes to the effective use of cognitive strategies. In the light of these findings, language teachers are obliged to apply strategy training in language classes because many learners are 
aware of some particular types of reading strategies, but they do not know how to apply these strategies to comprehend the reading material, and therefore, what they need is training in using these strategies for successful comprehension of academic materials (Onovughe \& Hannah, 2011).

Further, the results of analysis comparing the mean scores of the frequency of strategy use by the CG and Exp. indicated that the cognitive strategies were the most frequently used and preferred strategies by EFL learners, followed by the memory and metacognitive strategies as the next most frequently used strategies, a fact which is supported by the findings of Ozek \& Civelek (2006) and Naseri and Zaferanieh (2012) who found cognitive strategies as the most frequently used followed by metacognitive and compensation strategies as the next most frequently preferred strategies, and Tercanlioglu ( 2004) who found that L1 and ESL students showed clear preferences for cognitive strategies followed by metacognitive and support strategies. The results, however, contradict Shang (2010) who found that metacognitive strategies were the most frequently used strategies followed by the compensation, and then the cognitive strategies. The results also reveal that the least frequently used strategies by the Exp. group were affective, social, and compensation. The reason can be justified by the fact that the use of some individual strategies is related to the culture and educational system in Iran where the students have very limited opportunities to use functional strategies, watch English language TV shows, or go to movies spoken in English. Moreover, lack of contact with native speakers, and even insufficient sources to learn about their foreign language culture are other factors in this regard. The results of a study conducted in Iran by Zareie and Paktinat (2007) accord with this idea.

\section{Conclusion}

The findings of this study indicated that: a) explicit strategy instruction significantly increased the learners' frequency of reading strategies, b) the most frequently used reading strategies were cognitive, memory, and metacognitive, followed by compensation, social, and affective strategies. The results of this study on strategy training imply that language teachers are obliged to heighten their students' awareness of their own strengths and weaknesses in learning the language and the range of strategies they can choose in order to learn the target language most efficiently. The curriculum designers and language teachers can benefit from the findings of this study to design appropriate and effective textbooks for EFL learners by including effective reading strategies and ameliorate their method of teaching by integrating learner strategies into the reading classes. EFL learners can also take the most optimum use of reading process by utilizing effective and efficient reading strategies.

\section{References}

Anani sarab, M.R., \& Seif Reihani, M. (2010). Cognitive and metacognitive strategy use and second language reading test performance: The case of Iranian intermediate EFL learners. IJAL, 13(2), 1-18.

Anderson, N. J. (1991). Individual differences in strategy use in second language reading and testing. Modern Language Journal, 75(4), 460-472. http://dx.doi.org/10.1111/j.1540-4781.1991.tb05384.x

Anderson, N.J. (2002). The role of metacognition in second language teaching and learning. ERIC Digest, 1-5.

Chamot, A.U. (2004). Issues in language learning strategy research and teaching. Electronic Journal of Foreign Language Teaching, 1(1), 14-26.

Chamot, A.U., Barnhardt, S., El-Dinary, P.B., \& Robbins, J. (1999). The learning strategies handbook. White Plains, NY: Addison Wesley Longman.

Dreyer, C., \& Nel, C. (2003). Teaching reading strategies and reading comprehension within a technology-enhanced learning environment. System, 39, 349-365. http://dx.doi.org/10.1016/S0346-251X(03)00047-2

Fazilatfar, M. (2011). A study of reading strategies using task-based strategy assessment. Journal of English Language Teaching and Learning, 53(217), 19-44.

Garner, R. (1987). Metacognition and reading comprehension. Norwood, NJ: Ablex.

Horiba, Y. (2013). Task-induced strategic processing in L2 text comprehension. Reading in a Foreign Language, 25(2), 98-125.

Karbalaei, A. (2010). A comparison of the metacognitive reading strategies used by EFL and ESL readers. The Reading Matrix, 10(2), 165-180.

Khezrlou , S. (2012). Cognitive strategy training: Improving reading comprehension in the language classroom. The 
Journal of Teaching Language Skills, 3(4), 77-98.

Kirn, E., \& Hartmann, P. (2002). Interactions 2 reading ( $4^{\text {th }}$ edition). New York: McGraw Hill.

Kong, A. (2006). Connections between L1 and L2 readings: reading strategies used by four Chinese adult readers. The Reading Matrix, 6(2), 19-45.

Macaro, E., \& Erler, L. (2008). Raising the achievement of the young-beginner readers of French through strategy instruction. Applied Linguistics, 29(1), 90-119. http://dx.doi.org/10.1093/applin/amm023

Mokhtari, K., \& Sheorey, R. (2002). Measuring ESL students' awareness of reading strategies. Journal of Developmental Education, 25(3), 2-10.

Nahatame, S. (2014). Strategic processing and predictive inference generation in L2 reading. Reading in a Foreign Language, 26(2), 54-77.

Naseri, M., \& Zaferanieh, E. (2012). The relationship between reading self-efficacy beliefs, reading strategy use and reading comprehension level of Iranian EFL learners. World Journal of Education, 2(2), 64-75. http://dx.doi.org/10.5430/wje.v2n2p64

O’Malley, J. M., \& Chamot, A. U. (1990). Learning strategies in second language acquisition. Cambridge: Cambridge University Press. http://dx.doi.org/10.1017/CBO9781139524490

Onovughe, O. G., \& Hannah, A. T. (2011). Assessing ESL students' awareness and application of metacognitive strategies in comprehending academic material. Journal of Emerging Trends in Educational research and Policy Studies, 2(5), 343-346.

Oxford, R. L. (1990). Language learning strategies: What every teacher should know. Boston: Heinle \& Heinle.

Oxford, R. L. (1992). Language learning strategies in a nutshell: Update and ESL suggestions. TESOL Journal, 2(2), $18-22$.

Oxford, R. L. (2003). Language learning styles and strategies: An overview. GALA, 1-25.

Ozek, Y., \& Civelek, Y. (2006). A study on the use of cognitive reading strategies by ELT students. The Asian EFL Journal, 1-26.

Phakiti, A. (2006). Theoretical and pedagogical issues in ESL/EFL teaching of strategic reading. TESOL, 1, 19-50.

Poole, A. (2009). The relationship of reading proficiency to online strategy use: A study of U.S. college students. Journal of College Literacy and learning, 35, 3-11.

Pressley, M., \& Afflerbach, P. (1995). Verbal protocols of reading: The nature of constructively responsive reading. Hillsdale, NJ: Erlbaum.

Rokhsari, S. (2012). An investigation of reading strategies used by Iranian EFL intermediate readers. Journal of Academic and Applied Studies, 2(8)\&(9), 1-21.

Salataci, R., \& Aykel, A. (2002). Possible effects of strategy instruction on L1 and L2 reading. Reading in a Foreign Language, 14(1), 1-23.

Shang, H.F. (2010). Reading strategy use, self-efficacy, and EFL reading comprehension. The Asian EFL Journal Quarterly, 12(2), 18-24.

Singhal, M. (2001). Call for reading skills in English: An interactive web program for college-level ESL students. Papers from ITMELT 2001 conference. Retrieved April, 02, 2009, from http://elc.polyu.edu.hk/ conference/papers 2001/ singhal.htm

Tercanlioglu, L. (2004). Postgraduate students' use of reading strategies in L1 and ESL context: Links to success. International Educational Journal, 5(4), 562-570.

Zareie, G. R., \& Paktinat, A. (2007). Language learning strategies among pre- university and the relationship between their teacher' s advice and students' proficiency level. Roshd FLT, 22(85), 45-52.

Zhang, L. J., \& Wu., A. (2009). Chinese senior high school EFL students' metacognitive awareness and reading strategy use. Reading in a Foreign Language, 21(1), 37-59. 